\title{
GAMUT OF INK JET PRINTS In FunCTION OF THE ENVIRONMENT
}

\author{
DOBRIC, E.; BOLANCA, Z. \& SINDJIC, I.
}

Abstract: The aim of this work is the result presentation of the gamut investigations of ink jet prints obtained: immediately after the printing, including the print drying phase, the ageing of prints in the closed space without the influence of radiation, exposing the prints to the mixed daylight and artificial light and exposing of prints to the sun-light through the glass window. The prints obtained by piezo-electric and thermal ink jet technologies were used in investigations. The dye-based inks and the pigmented inks based on water and the low-solvent inks were used. The results of these investigations, except the scientific contribution in the domain of understanding and explaining the environmental conditions on the gamut size, i.e. the range of color tonality and print quality, can be used by the ink and paper manufacturers in new formulations, as well as the printer producers for further production and evaluation of the position of their products.

Key words: ink jet, dye-based ink, pigmented ink, gamut, environment
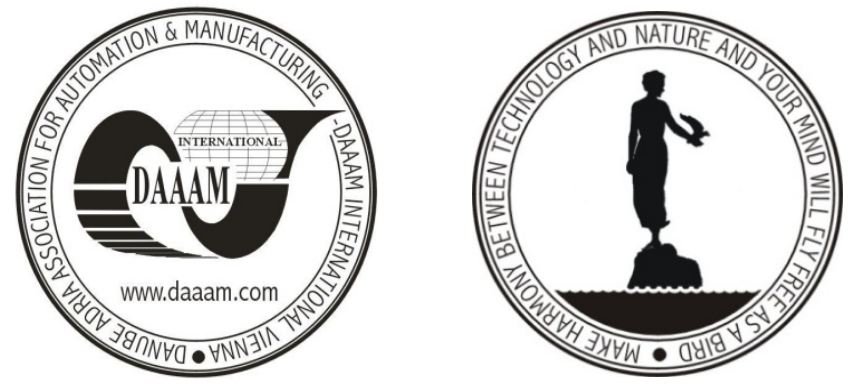

Authors' data: PhD. Student Dobric, E[ugen]; Prof. PhD. Bolanca, Z[denka], PhD. Student Sindjic, I[gor], University of Zagreb, Faculty of Graphic Arts, Getaldiceva 2, 10000, Zagreb, Croatia, eugen.dobric@gmail.com, zbolanca@grf.hr, igor@vectordesign.hr

This Publication has to be referred as: Dobric, E[ugen]; Bolanca, Z[denka] \& Sindjic, I[gor] (2009). Gamut of Ink Jet Prints in Function of the Environment, Chapter 68 in DAAAM International Scientific Book 2009, pp. 703-712, B. Katalinic (Ed.), Published by DAAAM International, ISBN 978-3-901509-69-8, ISSN 17269687,Vienna, Austria

DOI:10.2507/daaam.scibook.2009.68 